\title{
Inhaled steroids in exacerbations of COPD
}

\section{To the Editors:}

I read with interest the recent article by GUNEN et al. [1], wherein the authors presented the hypothesis that nebulised budesonide might be an alternative to systemic corticosteroids in the treatment of patients with exacerbations of chronic obstructive pulmonary disease (COPD). There are certain points which need discussing regarding their hypothesis of nebulised inhaled corticosteroids in COPD exacerbations.

First, exacerbations of COPD were considered to be a purely local disease: there is now enough evidence to support that COPD is, on the contrary, a systemic disease. Exacerbations of COPD are associated with increased levels of soluble markers of systemic inflammation in the serum [2], and the systemic inflammatory response at exacerbation is proportional to that occurring in the lower airway and is greater in the presence of a bacterial pathogen.

Secondly, the grading of the severity of acute COPD exacerbations is still a controversial issue and the inflammatory response may differ with the severity of exacerbation. In mildto-moderate exacerbations there is an increase in neutrophils and eosinophils in sputum and the airway wall [3]; while in severe exacerbations there is marked increase in neutrophils [4].

Thirdly, the precipitating cause for exacerbation was not taken into consideration, as patients with COPD exacerbations related to viral and bacterial origin have a significant eosinophilic response which may respond very well to inhaled corticosteroids [5]. Neutrophilic inflammation is generally resistant to corticosteroids, whereas eosinophilic inflammation is suppressed. Corticosteroids decrease the survival of eosinophils in vitro, whereas they prolong the survival of neutrophils by inhibiting apoptosis [6].

Fourthly, it has been seen that $\sim 10 \%$ of the patients with stable obstructive disease have overlapping features of both asthma and COPD, and these patients may show a beneficial response to steroids [7]. Even in asthma that is highly steroid responsive, high-dose inhaled steroids could not replace oral prednisolone in children with moderate-to-severe acute asthma [8].

Finally, the systemic absorption of such a high dose of inhaled corticosteroids should be kept in mind. Following nebulised administration of budesonide, $\sim 6 \%$ of the dose reaches the systemic circulation. Systemic absorption of the inhaled corticosteroids could have explained the beneficial effects of inhaled steroids noted in the study. Nebulised budesonide in a
$1 \mathrm{mg}(1,000 \mu \mathrm{g})$ dose produced anti-asthmatic and systemic effects equivalent to $35 \mathrm{mg}$ and $7.6 \mathrm{mg}$ of prednisone, respectively [9]. Moreover, there is a ceiling of the beneficial effect of nebulised steroids beyond $1,600 \mu \mathrm{g} \cdot \mathrm{day}^{-1}$.

\author{
A. Singh \\ Christian Medical College and Hospital, Ludhiana, India.
}

\section{STATEMENT OF INTEREST}

None declared.

\section{REFERENCES}

1 Gunen H, Hacievliyagil SS, Yetkin O, Gulbas G, Mutlu LC, In E. The role of nebulised budesonide in the treatment of exacerbations of COPD. Eur Respir J 2007; 29: 660-667.

2 Hurst JR, Perera WR, Wilkinson TM, Donaldson GC, Wedzicha JA. Systemic and upper and lower airway inflammation at exacerbation of chronic obstructive pulmonary disease. Am J Respir Crit Care Med 2006; 173: 71-78.

3 Wedzicha JA. Exacerbations: etiology and pathophysiologic mechanisms. Chest 2002; 121: Suppl. 5, 136S-141S.

4 Drost EM, Skwarski KM, Sauleda J, et al. Oxidative stress and airway inflammation in severe exacerbations of COPD. Thorax 2005; 60: 293-300.

5 Papi A, Bellettato CM, Braccioni F, et al. Infections and airway inflammation in chronic obstructive pulmonary disease severe exacerbations. Am J Respir Crit Care Med 2006; 173: 1114-1121.

6 Meagher LC, Cousin JM, Seckl JR, Haslett C. Opposing effects of glucocorticoids on the rate of apoptosis in neutrophilic and eosinophilic granulocytes. J Immunol 1996; 156: 4422-4428.

7 Beeh KM, Kornmann O, Beier J, Ksoll M, Buhl R. Clinical application of a simple questionnaire for the differentiation of asthma and chronic obstructive pulmonary disease. Respir Med 2004; 98: 591-597.

8 Schuh S, Dick PT, Stephens D, et al. High-dose inhaled fluticasone does not replace oral prednisolone in children with mild to moderate acute asthma. Pediatrics 2006; 118: 644-650.

9 Toogood JH, Baskerville J, Jennings B, Lefcoe NM, Johansson SA. Bioequivalent doses of budesonide and prednisone in moderate and severe asthma. J Allergy Clin Immunol 1989; 84: 688-700. 